\title{
PENINGKATAN KETRAMPILAN PETERNAK SUSU PERAH DALAM PROSES PENANGANAN PEMERAHAN SUSU DI MITRA PRODUKSI SUSU PASTEURISASI BERBASIS TEKNOLOGI MEDAN PULSA LISTRIK TEGANGAN TINGGI
}

\section{IMPROVING SKILLS OF MILK FARMERS IN THE PROCESS OF HANDLING MILK IN POSTTEURIZED MILK PRODUCTION PARTNERS BASED ON HIGH VOLTAGE ELECTRIC PULSE}

\author{
Feby Erawantini ${ }^{1}$, Budi Hariono ${ }^{2}$, Azamataufiq Budiprasojo ${ }^{3}$, Trismayanti Dwi Puspitasari ${ }^{4}$ \\ ${ }^{1}$ Jurusan Kesehatan, Politeknik Negeri Jember \\ ${ }^{2}$ Jurusan Teknologi Pertanian, Politeknik Negeri Jember \\ ${ }^{3}$ Jurusan Teknik, Politeknik Negeri Jember \\ ${ }^{4}$ Jurusan Teknik Informatika, Politeknik Negeri Jember \\ Jalan Mastrip Jember PO Box 164 Jember \\ feby erawantini@polije.ac.id \\ ${ }^{2}$ budi harionodpolije.ac.id \\ 3 azamataufiq@polije.ac.id \\ trismayanti@polije.ac.id
}

Abstrak

Susu merupakan bahan pangan sempurna karena mempunyai nilai gizi lebih baik dibandingkan dengan nilai gizi sumber pangan lainnya. Produk susu mempunyai sifat tidak tahan lama dan mudah rusak (perishable food) dan berpotensi mengandung bahaya (potentially hazardous food/PHF). Susu diperah dari ambing ternak sehat tidak bebas dari mikroba dan mengandung sampai 500 organisme/ml, jika ambing pada ternak sakit maka jumlah mikroorganisme dapat meningkat menjadi 20.000 mikroorganisme/ml. Ambing susu ternak dapat menjadi sumber pencemaran mikroorganisme, karena mikroorganisme dapat tumbuh dan berkembang sedikit agak jauh kedalam puting yang tidak tertutup dan biasanya dalam kondisi basah. Mikroorganisme terbawa sebagai sumber pencemaran, ketika susu mulai diperah, bagian pertama dari pemerahan biasanya dibuang karena dapat mengandung hingga 50.000 mikroorganisme/ml. Sumber pencemaran lain dapat berasal dari lingkungan kandang (lantai, udara, debu dan air), tubuh dan kotoran kambing, pakan, peralatan pemerahan, pekerja, pencemaran selama penyimpanan dan pemasaran. Kandungan mikroorganisme pada susu merupakan fungsi dari waktu, penanganan susu menentukan jenis mikroorganisme yang terbawa, sedangkan suhu penyimpanan menentukan kecepatan perkembangbiakan mikroorganisme. Kualitas bahan baku susu menjadi faktor utama keberhasilan penerapan teknologi pasteurisasi susu metode medan pulsa listrik tegangan tinggi. Metode yang digunakan untuk menghitung jumlah mikroba adalah Total Plate Count (TPC) sesuai SNI 2897-2008. Hasil yang diperoleh dengan menerapkan SOP pemerahan susu diperoleh jumlah mikroba pada susu segar sebesar 6,91 x $10^{2} \mathrm{cfu} / \mathrm{ml}$ dan hasil susu yang telah dipasteurisasi dengan teknologi HPEF sebesar $1,96 \times 10^{2} \mathrm{cfu} / \mathrm{ml}$ atau menurunkan total mikroba sebesar $76 \%$.

Kata kunci : SOP Pemerahan Susu, Teknologi HPEF

Abstract

Milk is a perfect food ingredient because it has better nutritional value or rich in many nutrients essential than other food sources. Dairy products are perishable food and potentially contain dangerous ingredients or Potentially Hazardous Food (PHF). Healthy udder livestock usually contains up to 500 organisms / ml microbes. If udder is sick, the number of microorganisms can increase to 20,000 microorganisms / ml. Udder milk can be a source of microorganism contamination, because it can grow and develop into nipples that are not closed and in wet conditions. Microorganisms are carried away as a source of pollution, when milk starts to be expressed, the first part of milking is usually discarded because it can contain up to $\mathbf{5 0 , 0 0 0}$ microorganisms / $\mathbf{m l}$. Other sources of pollution can come from the stable environment (floor, air, dust and water), cow dung and body, feed, milking equipment, workers, pollution during storage and marketing. The content of microorganisms in milk is a function of time, the handling of milk determines the type of microorganisms carried, while the storage temperature determines the proliferation of microorganisms. The quality of the raw material for milk is a major factor in the successful application of the pasteurization technology for the high voltage electric pulse field method. The method to calculate the number of microbes is Total Plate Count (TPC) according to SNI 2897-2008. The results obtained by applying the SOP for milking showed that the number of microbes in fresh milk was $6.91 \times 10^{2} \mathrm{cfu} / \mathrm{ml}$ and the milk that had been pasteurized with HPEF technology was $1.96 \times 10^{2} \mathrm{cfu} / \mathrm{ml}$ or decreased the total microbe by $76 \%$.

Keywords : HPEF technology, milk processing 


\section{PENDAHULUAN}

Susu dikenal sebagai bahan pangan cair sempurna dikarenakan terkandung nilai gizi lebih baik dibandingkan produk pangan lainnya [1] Sudono 1983). Susu merupakan produk pangan yang tidak tahan bila disimpan pada susu ruang dan mudah rusak (perishable food) serta berpotensi mengandung bahaya (potentially hazardous food/PHF). Susu mengandung komponen penting seperti protein, lemak, vitamin, mineral, laktosa, enzim-enzim dan beberapa mikroba [2] Lampert 1980). Tolok ukur mutu produk susu adalah kandungan protein dan lemak. Semakin tinggi kandungan protein dan lemak pada produk susu maka memberikan insentif harga lebih tinggi.

Susu merupakan medium paling baik untuk tumbuh kembang mikroorganisme, karena komposisi nutrisi yang dikandung susu sangat ideal. Sebagai contoh, susu dalam ambing ternak sehat tidak bebas dari mikroba dan mengandung sampai 500 organisme/ml, jika ambing pada ternak sakit maka jumlah mikroorganisme dapat meningkat menjadi 20.000 mikroorganisme/ml [3] Buckle at al. 2009). Puting susu pada ternak dapat menyebabkan pencemaran mikroorganisme, karena mikroorganisme dapat tumbuh sedikit agak jauh ke dalam puting yang tidak tertutup dan biasanya dalam kondisi basah. Mikroorganisme terbawa sebagai sumber pencemaran, ketika susu mulai diperah, bagian pertama dari pemerahan biasanya dibuang karena dapat mengandung hingga 50.000 mikroorganisme/ml.

Sumber pencemaran lain dapat berasal dari lingkungan kandang (lantai, udara, debu dan air), tubuh dan kotoran kambing, pakan, peralatan pemerahan, pekerja, pencemaran selama penyimpanan dan pemasaran. Kandungan mikroorganisme pada susu merupakan fungsi dari waktu, penanganan susu menentukan jenis mikroorganisme yang terbawa, sedangkan suhu penyimpanan menentukan kecepatan perkembangbiakan mikroorganisme [3] Buckle et al. 2009). Jumlah mikroorganisme pada produk susu umumnya sangat tinggi sehingga perlu persyaratan khusus agar aman dikonsumsi.

Membantu peternak menjaga kualitas susu segar untuk memperpanjang umur simpan merupakan tantangan dan permasalahan yang harus diselesaikan. Teknologi penanganan dan pengolahan susu yang aplikatif dan tepat guna, serta mengikuti tata cara pengolahan yang baik dan benar (Good Manufacturing Practices) dengan mempraktekkan kaidah-kaidah higien dan sanitasi (Sanitation Standar Operating Procedures), perlu ditekankan kepada peternak dan produsen susu pasteurisasi untuk memberikan jaminan keamanan dan kualitas produk olahan asal susu.

Kerusakan susu sangat merugikan dan menyebabkan timbulnya masalah dalam proses pasteurisasi susu untuk layak dikonsumsi secara langsung sebagai susu segar [4] Muchtadi \& Sugiyono 1992). Karenanya kualitas susu perlu diperhatikan dan terjamin sampai susu siap dikonsumsi. Kriteria umum kualitas susu adalah pencemaran mikroorganisme di dalam susu. Menurut UU tentang pangan yaitu No.7 tahun 1996, pengertian keamanan pangan adalah kondisi dan upaya yang diperlukan untuk mencegah bahan pangan dari kemungkinan cemaran biologis, kimia dan benda-benda lain yang dapat mengganggu, merugikan dan membahayakan kesehatan manusia.

Sejalan dengan perkembangan industri susu, parameter kualitas susu tidak lagi didasarkan pada kandungan protein dan lemak saja, akan tetapi ditambah dengan parameter kandungan mikroba dalam susu. Oleh karena itu menjadi sangat penting untuk mempertahankan kualitas susu segar ditinjau dari aspek fisik, kimia dan mikrobiologis. Kualitas susu yang baik memberikan hasil yang maksimal pada proses produksi susu dengan metode HPEF.

Metode HPEF ini berada dalam temperatur yang jauh dibawah dari metode pasteurisasi tradisional. Metode ini menggunakan pulsa tegangan tinggi diantara dua elektroda untuk menghasilkan suatu intensitas medan listrik yang tinggi dengan waktu yang singkat. Kelebihan proses pasteurisasi metode $H P E F$ antara lain : proses pasteurisasi menjadi lebih efektif, mudah, murah, dan aman. Proses pasteurisasi metode HPEF menyebabkan tingkat kesegaran produk susu terjamin secara maksimal, penampakan fisik tidak mengalami perubahan berarti, sehingga akan dicapai standar kualitas produk yang lebih baik. Dengan demikian akan diperoleh daya saing produk di pasaran yang lebih baik

\section{TARGET DAN LUARAN}

Khalayak Sasaran dari kegiatan ini adalah UKM Susu Rembangan, dengan pemilik ibu Arianti Fani Dwi Agus L dari Desa Kemuning Lor Arjasa Jember yang mempunyai 8 ekor sapi perah. Rata-rata produksi susu sapi sebesar 120 liter per hari dengan omset kotor sebelum dikurangi pakan dan tenaga kerja sebesar Rp1.440.000,-/hari dimasa normal. Susu sapi perah hanya dijual ke pengepul susu dengan harga Rp. 10.000 - Rp 12.000 per liter. Target khusus kegiatan pengabdian UKM Indonesia Bangkit ini adalah: (1) 
Penerapan Teknologi proses sterilisasi dengan HPEF sistem batch dengan kapasitas 5 liter, (2) Ketrampilan penerapan SOP Pemerahan Susu. Luaran kegiatan: (1) Produk susu pasteurisasi metode $H P E F$, (2) Modul aplikasi HPEF.

\section{METODE PELAKSANAAN}

Metode Pengabdian

\section{Tahap Persiapan dan Koordinasi dengan Mitra}

Tim pelaksana kegiatan bersama dengan mitra melakukan focus group discussion (FGD) untuk membahas kendala yang ada di lapangan dan membuat kesepakatan solusi yang akan dituangkan dalam program ini. Sekaligus menentukan target atau sasaran yaitu peserta yang akan perpartisipasi dalam program ini.

\section{Studi Literatur Hasil Riset Manajerial}

Aspek menejerial meliputi meninngkatkan pemahaman anggota UKM terhadap fungsi-fungsi manajemen. Pengurusan ijin usaha dan ijin Dinas Kesehatan atau Badan POM, merk dagang.

3. Studi Literature Hasil Riset Teknologi Pemasaran/ Distribusi dengan Digital Marketing

Pemasaran susu sapi rembangan dengan digital marketing yaitu melalui website dan melalui platform e-commerce.

\section{Implementasi SOP Pemerahan Susu di Mitra}

SOP yang dirujuk dan diimplementasikan di mitra adalah Standar Operasional rosedur (SOP) ISO 9001 : 2008 dengan No. 01100106407 dari Balai Besar Pembibitan Ternak Unggul Dan Hijauan Pakan Ternak (BBPTUHPT) Baturraden Tahun 2016.

5. Mengimplementasikan aspek Peningkatan kapasitas teknologi (Proses Produksi) dengan Implementasi $\mathrm{HPEF}$

Diversifikasi susu pasteurisasi panas (termal) menjadi produk susu pasteurisasi non termal (tanpa panas) metode HPEF. HPEF merupakan teknologi pasteurisasi baru tidak melibatkan panas, karena perlakuan panas pada metode $H P E F$ ini berada dalam temperatur yang jauh dibawah dari metode sterilisasi tradisional. Metode ini menggunakan pulsa tegangan tinggi diantara dua elektroda untuk menghasilkan suatu intensitas medan listrik yang tinggi. Tegangan yang dihasilkan mencapai $80 \mathrm{kV}$, dapat menyebabkan kematian mikroorganisme (inaktivasi mikroba) dengan tidak mengurangi kualitas nutrisi dan sifat-sifat arganoleptik dari produk. Oleh sebab itu, sifat arganoleptik (aroma, rasa, warna, dan tekstur) dan nilai nutrisi bahan pangan cair yang diolah tetap seperti pada produk segar.

\section{Uji Laboratorium}

Uji laboratorium untuk pengujian total mikroba menggunakan SNI 2897-2008 dilaksanakan di Laboratorium Bioscience Politeknik Negeri Jember.

\section{HASIL DAN PEMBAHASAN}

4.1 Implementasi Standar Operasional rosedur (SOP) ISO 9001 : 2008 dengan No. 01100 106407

\subsubsection{Pemerahan dan Penimbangan Produksi Susu}

\subsubsection{Pemerahan}

a. Persiapan

1. Mempersiapkan bahan dan peralatan yang sudah bersih dan hieginies.

2. Mempersiapkan lingkungan pemerahan yang bersih dan nyaman untuk proses pemerahan

b. Pelaksanaan

1. Pemerahan dilakukan 2 kali sehari yaitu pagi (jam $03.00 \mathrm{wib}$ ) dan siang hari (12.00 wib)

2. Menenangkan sapi yang akan diperah agar pemerahan berjalan lancar.

3. Pekerja yang akan melaksanakan pemerahan harus mencuci tangan dengan bersih supaya air susu hasil pemerahan sehat, bersih dan tidak tercemar kotoran dan benda asing dari tangan pemerah.

4. Sebelum diperah, ambing dibersihkan dahulu dengan desinfectan, ambing dikeringkan dengan kertas tissue.

5. Setelah puting dikeringkan, kemudian lakukan satu atau dua pancaran perahan awal (stripping) dari setiap puting dibuang.

6. Puting dari sapi yang akan diperah perlu diolesi pelumas supaya menjadi licin sehingga memudahkan proses pemerahan dan sapi tidak merasa sakit

7. Sesudah pemerahan selesai ambing dibersihkan kembali serta di dipping dengan desinfectan, bersihkan dan simpan peralatan pemerahan sesudah kegiatan pemerahan selesai

\subsubsection{Penimbangan Produksi Susu}

a. Persiapan

1. Menyiapkan alat dan bahan pemerahan.

b. Pelaksanaan

1. Melaksanakan Penimbangan produksi susu

2. Mencatat data produksi susu

3. Melakukan serah terima produksi susu

\subsubsection{Pemantauan Produksi Susu Harian}

a. Persiapan

1. Menyiapkan alat tulis dan form penimbangan produksi susu harian.

b. Pelaksanaan

1. Lakukan penyalinan data produksi susu harian dari form penimbangan produksi susu harian kedalam buku produksi susu harian. 
2. Lakukan pemantauan produksi susu harian dengan cara membandingkan produksi hari itu dengan produksi hari sebelumnya.

3. Lakukan pencermatan data penurunan / kenaikan produksi susu harian yang extrim.

4. Informasikan kepada bagian terkait : bagian Pemeliharaan, bagian penyediaan pakan, bagian kesehatan hewan dan bagian reproduksi.

c. Penyelesaian

1. Memasukkan data pemantauan produksi susu harian ke dalam DPM-YB-04-02-00.

2. Lakukan pencatatan kasus produksi ekstrim sebagai dasar evaluasi guna penentuan kebijakan lebih lanjut.

3. Laporkan hasil pemantauan produksi susu harian secara periodik kepada kepada petugas penyuluh.

\subsection{Implementasi Teknologi HPEF}

Peralatan yang dihibahkan ke mitra program UKM Indonesia Bangkit tertera pada Gambar 1 .

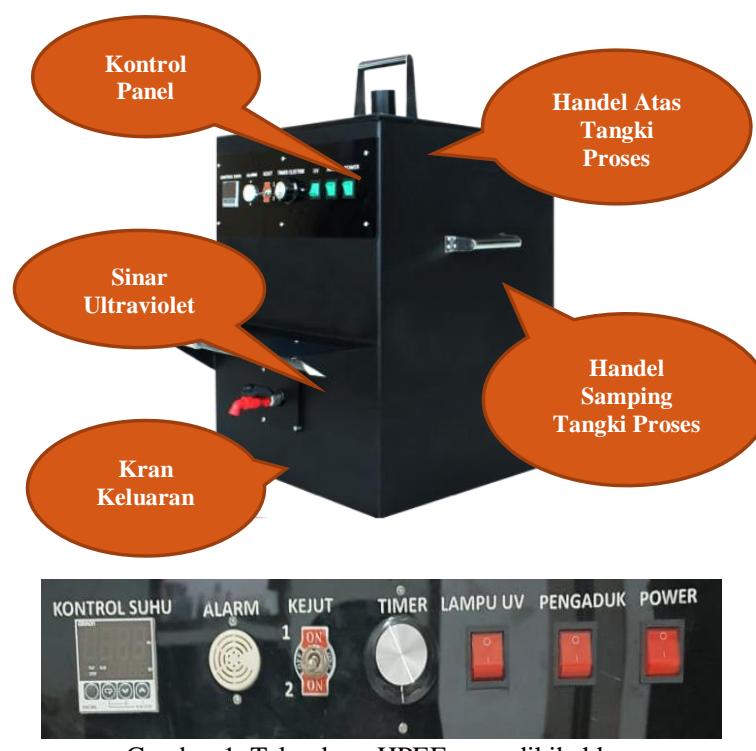

Gambar 1. Teknologo HPEF yang dihibahkan

\section{FUNGSI ANATOMI MESIN :}

1. Kontrol Panel:

Berfungsi sebagai tempat panel panel tombol dan indicator untuk mengoperasikan mesin PEF.

2. Handel Atas Tangki Proses:

Berfungsi untuk membuka tabung pengolahan susu yang akan diproses menggunakan mesin PEF

3. Handel Saamping tangka proses:

Berfungsi untuk pegangan tangan saat memindahkan mesin.

4. Lampu UV:
Berfungsi untuk mensterilkan susu yang keluar dari kran keluaran.

5. Kran Keluaran:

Berfungsi untuk mengeluarkan susu yang sudah selesai diproses dengan mesin HPEF

\section{FUNGSI BAGIAN KONTROL PANEL :}

1. KONTROL SUHU:

Berfungsi mengatur temperatur susu agar selalu berada pada temperatur ideal selama proses pengolahan susu. Melalui kontrol suhu dapat mengatur naik dan turunnya suhu menggunakan tombol ATAS dan BAWAH. Suhu rekomendasi $=33{ }^{\circ} \mathrm{C}$

2. ALARM

Berfungsi untuk memberikan tanda berupa suara, ketika susu sudah selesai diolah.

3. KEJUT

Berfungsi menyalakan (ON) dan mematikan (OFF) aliran listrik ke susu selama proses pengolahan. Posisi 1 pada knob adalah ON dan posisi 2 pada knob adalah OFF.

4. TIMER

Berfungsi untuk mengatur waktu lama pengadukan susu yang diproses. Waktu Yang direkomendasikan adalah 3 menit, dengan memutar knob hingga tanda putih ada pada bagian bawah.

5. LAMPU UV

Berfungsi menyalakan ( I ) dan mematikan ( O ) lampu ultraviolet (UV) pada bagian bawah mesin. Posisi ( I ) pada saklar adalah ON dan posisi ( $\mathrm{O}$ ) pada saklar adalah OFF.

6. PENGADUK

Berfungsi menyalakan ( I ) dan mematikan ( O ) lampu ultraviolet (UV) pada bagian bawah mesin. Posisi ( I ) pada saklar adalah ON dan posisi ( O ) pada saklar adalah OFF.

7. POWER

Berfungsi menyalakan ( I ) dan mematikan ( O ) daya mesin. Posisi ( I ) pada saklar adalah ON dan posisi $(\mathrm{O})$ pada saklar adalah OFF.

\subsection{Hasil Pengujian}

Pengujian susu sapi dengan metode pasteurisasi HPEF menggunakan metode TPC (Total Plate Count) dengan dengan SNI 2897-2008 yang dilakukan di Laboratorium Bioscience Politeknik Negeri Jember. Hasil perhitungan total mikroba susu segar dan susu pasteurisasi tertera pada Tabel 1.

Tabel 1. Hasil pengujian

\begin{tabular}{|c|c|c|c|}
\hline No & Kondisi proses & Susu segar & Susu $H P E F$ \\
\hline 1 & $\begin{array}{l}\text { Kondisi proses : suhu } \\
\text { proses } 35^{\circ} \mathrm{C}, \text { volume } \\
\text { susu } 5 \text { liter, tegangan } 55 \\
\mathrm{kV} / \mathrm{cm} \text {, waktu proses } 1 \\
\text { detik }\end{array}$ & $\begin{array}{l}6,91 \times 10^{2} \\
\mathrm{cfu} / \mathrm{ml}\end{array}$ & $\begin{array}{l}1,96 \times 10^{2} \\
\mathrm{cfu} / \mathrm{ml}\end{array}$ \\
\hline
\end{tabular}


Proses HPEF mampu menurunkan/mereduksi sebesar $76 \%$. Inaktivasi mikroba ini sesuai dengan yang dijelaksn oleh Zimmermann (1986) dengan teori electrical breakdown, yang dikembangkan, dan Castro et al. (1993) dengan teori electroporation. Teori Electrical Breakdown menjelaskan mekanisme inaktivasi mikroba disebabkan pengaruh medan listrik sebagai berikut: membran sel diumpamakan sebagai kapasitor yang terisi larutan dielektrikum (Gambar a). Pada kondisi normal, beda potensial di antara celah adalah V', dimana dengan pengaruh medan listrik sebesar E maka beda potensial meningkat (Gambar b). Kondisi ini mengakibatkan ketebalan dinding sel mengecil (Gambar c). Kerusakan membran sel terjadi apabila beda potensial mencapai titik kritis sebesar Vc, hal ini terjadi bila terdapat intervensi pengaruh medan listrik yang mencukupi sebesar E. Pada tahap ini kerusakan dinding sel masih bersifat dapat pulih (reversible) (Gambar d), akan tetapi dengan terus bertambahnya pengaruh medan listrik maka akan menyebabkan kerusakan permanen (Gambar e) seperti ditunjukkan pada Gambar 2.

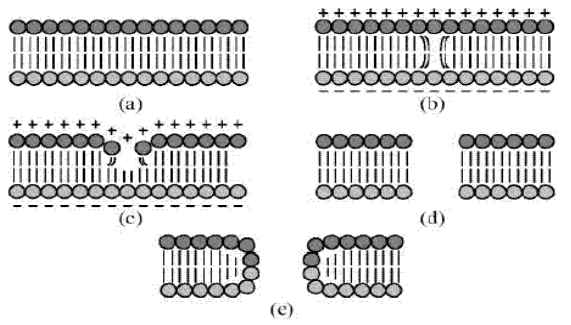

Gambar 12. Diagram skematik kerusakan elektrik (electrical breakdown) [9] Barbosa-Canovas et al. 1999;

Elektroporasi adalah destabilisasi membran sel karena pengaruh medan pulsa tegangan listrik sesaat [8] Castro et al. 1993). Menurut [10] VegaMercado et al. (1996) destabilisasi dinding sel diawali dari terjadinya gejala meningkatnya permeabilitas dinding sel $\quad-$ diikuti oleh penggelembungan dinding sel - dan akhirnya terjadi kerapuhan membran sel seperti ditunjukkan Gambar 3.

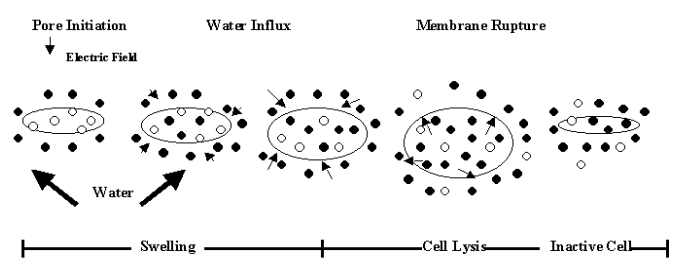

Gambar 3. Elektroporasi membran sel

Upaya untuk meningkatkan inaktivasi mikroba pada susu bisa dilakukan dengan teknologi hurdle, yaitu menggabungkan beberapa teknologi secara pararel seperti yang dilakukan [11] Hariono et al (2019) yang menghasilkan inaktivasi 0,98 log cyclus atau setara dengan kemampuan mereduksi mikroba sebesar $98 \%$.

\section{KESIMPULAN}

Kesimpulan dari kegiatan pengabdian UKM Indonesia Bangkit di mitra dengan penerapan teknologi HPEF adalah sebagai berikut.

1. Alat HPEF yang dihibahkan adalah sistem batch dengan kapasitas 5 liter susu.

2. Kondisi proses : suhu proses $35^{\circ} \mathrm{C}$, volume susu 5 liter, tegangan $55 \mathrm{kV} / \mathrm{cm}$, waktu proses 1 detik mampu mereduksi mikroba pada susu sapi sebesar $76 \%$.

3. Proses pemerahan di mitra sudah melaksanakan SOP pemerahan sehingga jumlah mikroba awal pada susu segar sebesar $6,91 \times 10^{2} \mathrm{cfu} / \mathrm{ml}$.

4. Mitra mengaplikasikan teknologi HPEF untuk produksi susu pasteurisasi non thermal metode HPEF dengan merk dagang "Susu Kejut"

\section{UCAPAN TERIMAKASIH}

Ucapan terima kasih disampaikan kepada pemberi Dana Hibah UKM Indonesia Bangkit Kementerian Riset Teknologi / Badan Riset Inovasi Nasional dengan no kontrak

\section{DAFTAR PUSTAKA}

[1] Sudono .1983. Produksi Sapi Perah, Depeartemen Ilmu Produksi Ternak,.Fakultas peternakan IPB. Bogor.

[2] Lampert, M L. 1980. Modern Dairy Product. New York: New York Publishing, Co. Inc.

[3] Buckle, K. A., R A Edwards G H Fleet dan M Wooton. 2009. Ilmu Pangan. Terjemahan Hari Purnomo dan Adiono. Jakarta: UI Press

[4] Muchtadi, T R dan Sugiyono. 1992. Ilmu Pengetahuan Bahan Pangan. Departemen Pendidikan dan Kebudayaan. Direktorat Jendral Pendidikan Tinggi. Pusat Antar Universitas. Institut Pertanian Bogor. Bogor.

[5] BBPTUHPT. 2006. Standar Operasional Prosedur (SOP). ISO 9001 : 2008 No. 01100 106407. Balai Besar Pembibitan Ternak Unggul Dan Hijauan Pakan Ternak (BBPTUHPT) Baturraden.

[6] SNI 2897-2008. Metode pengujian cemaran mikroba dalam daging, telur dan susu, serta hasil olahannya. Badan Standardisasi Nasional.

[7] Zimmermann U. 1986. Electrical breakdown, electropermeabilization and electrofusion. Rev Physiol Biochem Pharmacol. 105:175-256

[8] Castro AJ, Barbosa-Cánovas GV dan Swanson BG. 1993. Microbial inactivation of foods by pulsed electric fields. $J$ Food Proc Pr. 17:47-73.

[9] Barbosa-Cánovas GV, Gongora-Nieto MM, Pothakamury UR dan Swanson BG. 1999. Preservation of Foods with Pulsed Electric Fields. United States of America: Academic Pr.

[10] Vega-Mercado H, Pothakamury UR, Chang FJ, BarbosaCánovas GV, Swanson BG. 1996. Inactivation of Escherichia coli by combining $\mathrm{pH}$, ionic strength and pulsed electric fields hurdles. J Food Res Int. 29:117-121.

[11] Hariono B, R Wijaya, MF Kurnianto, Sutrisno, KB Seminar, A Brilliantina 2019. Quality of Goat's Milk Exposed Ultraviolet and High Pulsed Electric Field. Second International Conference on Food and Agriculture, IOP Conf. Series: Earth and Environmental Science 411. 